UDC 378:37.02:37.01/.09

Inna S. Zaiarna

PhD in Pedagogy, Assistant Professor, Foreign Languages Department

Law School, Taras Shevchenko National University of Kyiv, Kyiv, Ukraine

ORCID ID 0000-0002-9464-096X

izaiarna@gmail.com

\title{
ZOOM AS A TOOL OF WEB BASED TEACHING OF FOREIGN LANGUAGES TO STUDENTS OF HIGHER EDUCATION ESTABLISHMENTS IN UKRAINE
}

\begin{abstract}
Due to the COVID-19 pandemic a strict quarantine was imposed from March to May of 2020. Ukrainian higher education faced new challenges caused by unexpected distance teaching and learning implemented in all higher educational establishments during the period in question. Despite the sound theoretical achievements of Ukrainian scientists in the field of distance education, as well as the existing legal framework for the implementation of distance learning in higher education, not all educational institutions had well-established learning management systems. All the above induced foreign languages teachers to search for available technologies which allow delivering their lectures effectively. One of the most popular services was video conferencing, in particular Zoom.

The research deals with the specifics of teaching foreign languages in higher educational establishments on Zoom Platform via video conferencing. The research presents the results of the survey conducted among the teachers who used Zoom for teaching foreign languages during the quarantine from March to June in 2020. Based on the survey respondents' answers, the author determines benefits and drawbacks of Zoom for teaching foreign languages in higher educational establishments, specifies the factors for psychological comfort, as well as the conditions and tools for the development of language skills and speech abilities. Special attention is paid to methodological recommendations aimed at practical implementation of foreign languages online teaching via Zoom video conferencing. The author considers such aspects of foreign languages teaching via Zoom video conferencing as cyber security, discipline issues, creation of psychologically comfortable atmosphere, and Zoom technical tools for teaching foreign language communication.
\end{abstract}

Keywords: COVID-19; distance education; foreign languages teaching; methodological recommendations; video conferencing; Zoom.

\section{INTRODUCTION}

Statement of the problem. Under the circumstances of coronavirus disease (COVID19) pandemic, foreign language teachers in Ukraine have faced new challenges and threats related to the introduction of unexpected distance learning and teaching in all higher education institutions. Despite the sound theoretical achievements of Ukrainian scientists in the field of distance education, as well as the existing legal framework for its implementation in higher education, not all educational institutions in the spring of 2020 had well-established learning management systems such as LMS MOODLE. All the above induced foreign language teachers to search for available technologies allowing them to deliver their classes effectively. One of the most popular services among Ukrainian teachers turned out to be video conferencing.

According to the study conducted by GlobalLogic, the most popular video conferencing service was the Zoom platform, the demand for which during the quarantine in Ukraine increased ninefold [1]. The use of Zoom for educational process arrangement and establishment of effective communication with its participants during the quarantine also meets the official recommendations of the Ministry of Education and Science of Ukraine [2]. Moreover, our survey of 59 foreign language teachers also shows the popularity of the Zoom 
platform. It demonstrates that $54 \%$ of the respondents prefer the Zoom service to organize distance teaching of a foreign language in higher education, which significantly exceeds the use of other services for video conferencing such as Skype, which is utilized by $22 \%$ of the respondents, Google Meet, preferred by $11 \%$ or any other services, chosen by $13 \%$ of the survey respondents. Therefore, the growing demand for the Zoom platform among foreign language teachers in higher education encourages us to thoroughly analyze the technical capabilities of this service in order to devise clear recommendations that will help ensure a methodologically effective process of a foreign language teaching/learning via video conferencing. We consider it expedient to base this analysis not only on the technical characteristics of the Zoom service, but also on the practical results of its application by teachers of Ukrainian higher educational institutions. This will, firstly, specify the measures for using the service at foreign language classes in Ukrainian higher educational institutions, as well as identify existing difficulties regarding the development of students' foreign language competence via video conferencing.

It has become obvious that inevitable changes in Ukrainian education caused by its current transition to distance and/or blended one, as well as the increasing role of ICTs in educational process, motivate foreign language teachers to master the Zoom platform, its technical capabilities and effective principles of implementation in the educational process aimed at the development of students' foreign language competence.

The analysis of recent studies and publications in the field of foreign language teaching via video conferencing illustrates that the outlined issue is in the focus of special attention of worldwide scientific community. Various aspects of online teaching and learning via video conferencing have already been studied. Thus, the specifics of foreign language learning and teaching in Skype-videoconferencing environment have been examined by K. Kotula [3]. According to a conducted survey of 124 teachers, the researcher comes to the conclusion that the format of video conferencing proves its effectiveness for teaching foreign language, though some technical constraints of the service still exist. P. McAndrew et al. [4] also support the idea regarding the benefits of using video conferencing for interactive activities while teaching business French. Video conferencing as a means of developing speaking skills has been studied by B. Loranc-Paszylk [5]. In her research, the scientist addresses the results of a survey of participants of an international project, which was implemented via video conferencing between Polish and French universities. The specifics of teaching a foreign language in primary school have been studied by L.-T. Yu [6]. The researcher pays his attention to students' achievements during classes conducted via video conferencing, the technical aspects of using this service and those activities that are effective for teaching foreign language communication via videoconferencing. Y. Wang has also analysed the features of the NetMeeting service for online teaching/learning of a foreign language [7]. The researcher has proved that the new generation of services for video conferencing has all the necessary technical capabilities for teaching a foreign language and developing students' foreign language competence.

Equally important for us is the research of Ukrainian scientists concerning the implementation of information and communication technologies in educational process aimed at the development of students' foreign language competence. In this context, the works of N. Mayer [8], N. Shcherba [9], V. Svyrydiuk [10], A. Yurzhenko [11], I. Zaiarna [12; 13], O. Zhovnych [14] have been studied. The researchers prove the effectiveness of ICTs in the process of foreign language competence development, identify their advantages and typical difficulties related to their use, as well as describe successful approaches and principles of their application.

However, despite the wide interest of world scientific community in the issue of foreign language teaching/learning via video conferencing as well as the significant contribution of 
the domestic scholars to its theoretical development, the analysis of recent works and publications shows that there is little research on practical experience of video conference application in the educational process aimed at foreign language competence development in Ukrainian realities.

In view of the abovementioned, the purpose of this article is to study the specifics of the use of Zoom service by foreign language teachers in order to devise the guidelines for the organization of effective foreign language teaching via video conferencing on the Zoom platform. Our focus will be on didactic, psychological and technical aspects of foreign language teaching, which should serve as a basis for preparing recommendations for teachers on the methodologically effective organization of the educational process aimed at the development of students' foreign language competence.

\section{RESEARCH METHODS}

During the study a number of theoretical and empirical methods have been used. In particular, a critical analysis of scientific and educational literature, sources of applied nature on the methods of distance teaching/learning of foreign languages and the use of services for video conferencing allowed us to study the theoretical background of the issue and clarify those aspects which still require in-depth study.

To identify the specifics of students' foreign language competence development in the format of videoconferencing on the Zoom platform, we also conducted a survey among foreign language teachers of Ukrainian higher education institutions who during the quarantine in the spring of 2020 used Zoom at their classes.

Theoretical achievements of domestic and foreign scientists in the field of distance education, as well as the study of practical experience of online teaching allowed us to develop guidelines for effective foreign language teaching via videoconferencing on the Zoom platform.

\section{FINDINGS}

For this particular study, the concept of "video conference" we would define, considering A. Lototskaya and O. Pasichnyk' findings, as one of the modern methods of communication conducted online in real time on a specified day and time [15]. The components necessary for the use of video conferencing include the following: 1) video equipment for transmission and screen for image projection; 2) microphone and acoustic installation for sound transmission and reproduction; 3) the corresponding telecommunication network [16, p. 105]. The most spread platforms for video conferencing in Ukraine are Google Meet, Microsoft Teams, Skype, Telegram, Viber, WhatsApp, Zoom. In this article we consider in more detail the features of the Zoom service as one of the most common in Ukraine in the context of its use during foreign language classes in higher educational institutions.

Zoom [17] as a service for video conferencing and online meetings is designed for both individual and group classes. The Zoom application can be installed on a computer, a tablet, or on a smartphone. Any user can join the video conference by following the link or conference ID. Classes can be scheduled in advance, and links for regular meetings at a specific time can be created. The available learning tools offered by Zoom (virtual board, chat, screen demonstration, joint commenting, the ability to group students, etc.) create a potential opportunity for students to develop their foreign language competence effectively.

To identify the specifics of working on the Zoom platform in the context of its application at foreign language classes (which, of course, differs from, for example, lectures 
in legal disciplines or laboratory studies in science), we conducted a survey [18]. Its participants were 32 foreign language teachers of Ukrainian higher education institutions, who during the quarantine in March-June of 2020 used the Zoom service at their classes. Teachers were asked to answer questions regarding the specifics of foreign language teaching via Zoom video conferencing in order to identify the advantages and disadvantages of this service. In our focus there also were potential difficulties related to the development of students' foreign language competence as well as effective ways for overcoming them.

According to the results of the survey, the main advantages of using Zoom at foreign language classes include the following (Fig. 1): ease of mastering; high-quality connection; possibility to record a meeting; availability of various educational tools and functions (interactive whiteboard, virtual background, chat, screen sharing, joint commenting, the ability to divide students into pairs and groups).

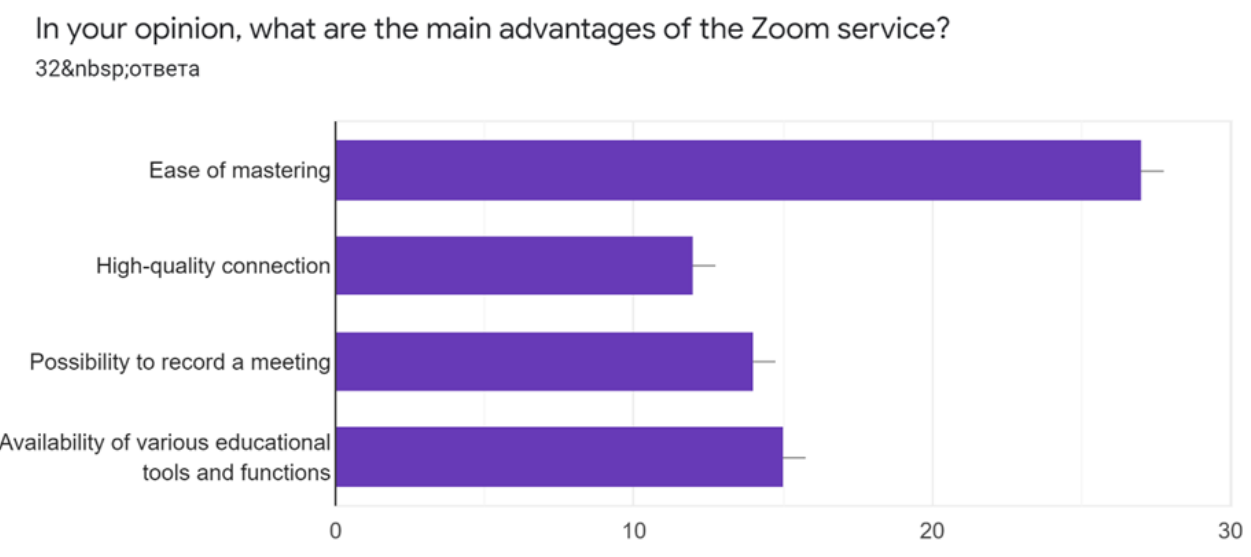

Figure 1. Benefits of the Zoom service as seen by foreign language teachers of Ukraine's higher educational institutions

Figure 2 illustrates the main disadvantages of using Zoom from the point of view of foreign language teachers participating in the survey. They include the following: 40-minute duration of the free version of the video conference, the inability to objectively assess students' achievements, the inability to conduct all the usual forms of work; technical problems; loss of live interpersonal communication, security issues.

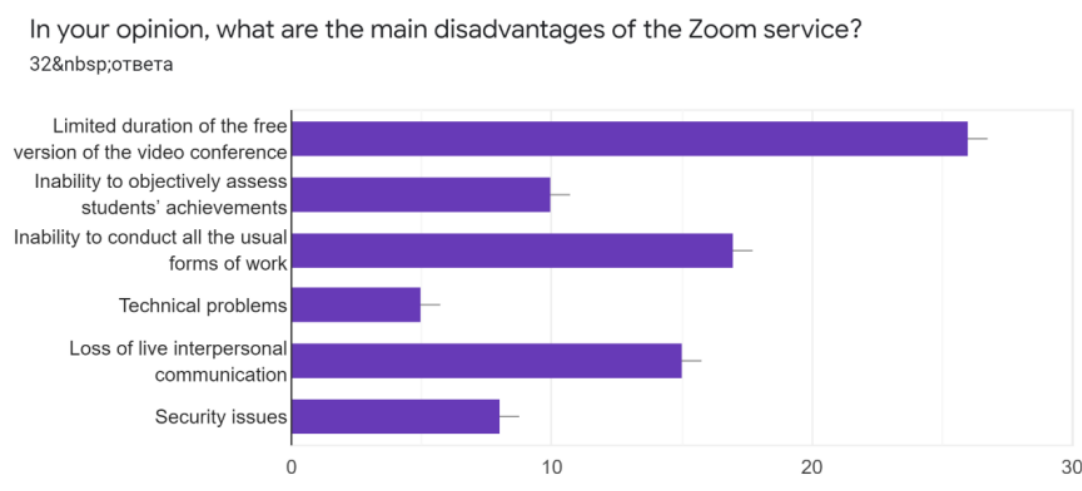

Figure 2. Disadvantages of the Zoom service as seen by foreign language teachers of Ukraine's higher educational institutions 
A thorough analysis of the survey responses allows us to state that the biggest advantage of the Zoom service is the ease of use (84.4\%), which was essential in the spring of 2020, when both teachers and students had to quickly find an alternative to face-to-face classes. Other important benefits include availability of various learning tools $(46.9 \%)$ that allow teachers to carry out different activities during online teaching, and the ability to record a meeting (43.8\%), which, in turn, provides teachers with an opportunity to analyse the lesson thoroughly in order to identify its strengths and weaknesses. At the same time, the biggest drawback, according to the respondents, is the limited duration of the free version $(81.3 \%)$, which leads to the interruption of the lesson. However, it should be noted that the learning process can be resumed immediately using the same link or conference ID. Other significant shortcomings highlighted by the respondents are the inability to carry out all the usual forms of work and the loss of interpersonal communication, $53.1 \%$ and $46.9 \%$ respectively. As for the first shortcoming, it is important to note that such percentage may have been caused not so much by objective factors such as technical aspects of the Zoom platform, but mostly by subjective ones, namely teachers' ignorance of all tools of the service or inability to use them properly in foreign language training. In addition, video conference provides additional learning opportunities such as conducting a quick real-time survey, access to Internet resources, etc. As for the loss of interpersonal communication, we completely agree that this is a serious problem during asynchronous distance learning/teaching; video conferencing, however, imitates real-time communication and in this way it supports cooperation among all the participants of the educational process.

At the same time, despite the difficulties faced by foreign language teachers in Ukrainian higher education institutions, they mostly achieved their educational goals. Thus, to the question: "How often did you achieve your learning goals and objectives during the lesson?" $68.8 \%$ of the respondents answered - "often", $12.5 \%$ answered - "always", $18.8 \%$ stated "rarely" (Fig. 3). Considering the fact that the achievement of educational goals is influenced by many factors, not just the online mode of the lesson, we believe that the fact of conducting classes via Zoom video conferencing cannot significantly affect its success.

\section{How often did you achieve your learning goals and objectives during the lesson? 32\&nbsp;ответа}

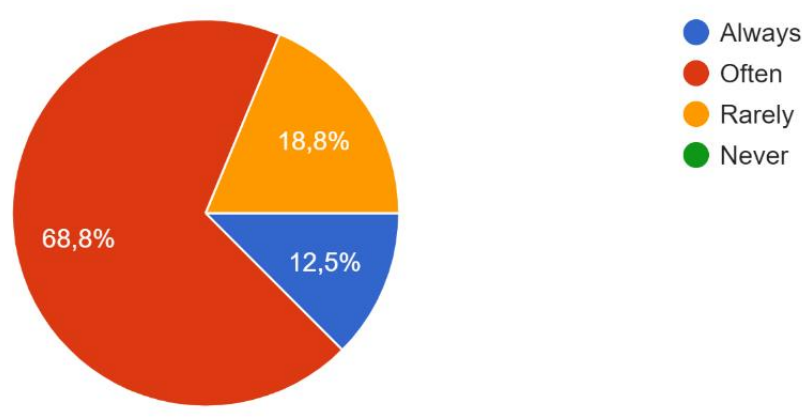

\section{Figure 3. Achievement of educational goals by foreign language teachers of Ukraine's} higher educational institutions while teaching via Zoom video conferencing

The results of the survey related to psychological comfort during online classes conducted via video conferencing are also vitally useful for us (Fig. 4). The survey shows that $25 \%$ of the respondents have never experienced psychological discomfort; $43.8 \%$ noted that they sometimes felt discomfort associated with the lack of live communication; $18.8 \%$ often felt discomfort and lack of human communication; $12.5 \%$ said they had always felt 
discomfort. Thus, the survey reveals a high percentage $(75.1 \%)$ of respondents who felt psychological discomfort during online classes carried out via video conferencing on the Zoom platform.

Have you ever felt psychological discomfort during your foreign language lessons conducted via Zoom video conferencing?

32\&nbsp;ответа
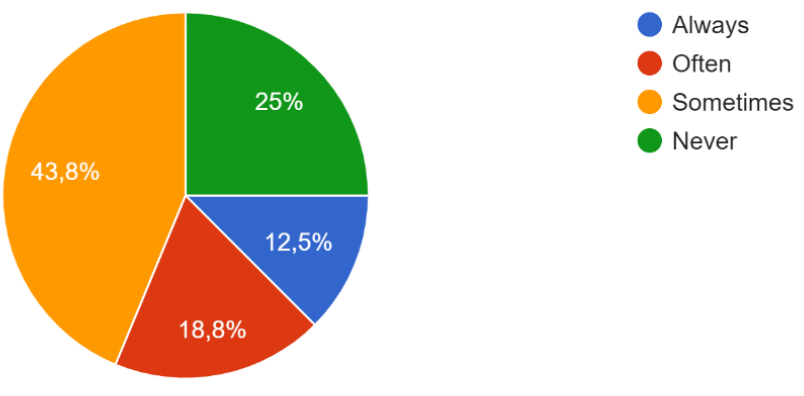

Figure 4. Psychological state of teachers during online lessons conducted via video conferencing on the Zoom platform

As for the main factors that negatively affected the psychological comfort during the classes, the respondents noted the following: students switched off video cameras; technical problems with connection; lack of live communication; inconvenience to work from home, insufficient level of mastery of technology, limited number of educational tools (Fig. 5).

In your opinion, what are the main factors that negatively affect the psychological comfort during the classes conducted via Zoom video conferencing?

32\&nbsp;ответа

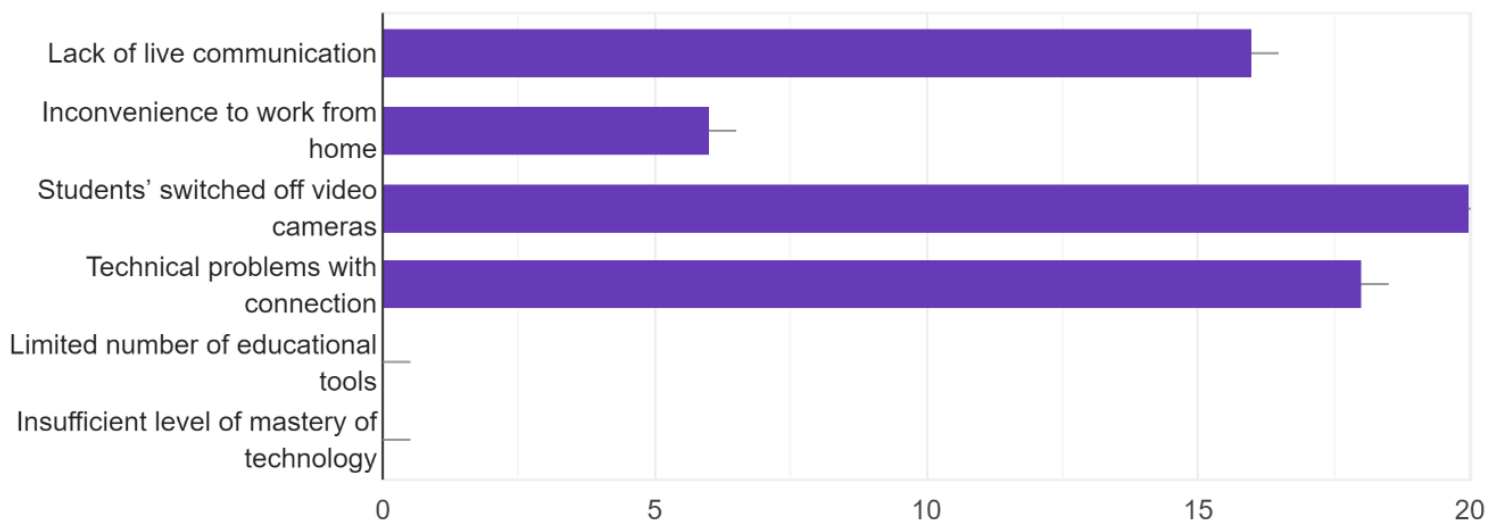

Figure 5. Negative factors that cause psychological discomfort during online classes conducted via Zoom video conferencing

Concerning the specifics of the issue under this research, our special attention is paid to a number of questions related to the development of language skills and speech abilities. According to the survey, $96.9 \%$ of the respondents used various Zoom tools to develop students' grammar and lexical skills. The following tools were used for this purpose: screen 
sharing, virtual whiteboard, chat. $84.4 \%$ of the respondents used Zoom to develop reading and listening skills. As for the development of productive skills (writing and speaking), the results were as follows: $100 \%$ of the respondents used Zoom to develop speaking skills and $65.6 \%$ to develop writing skills. Thus, we can conclude that teachers have actively used various tools of the Zoom service to teach language skills and speech abilities.

In general, according to our survey of the 32 foreign language teachers who used Zoom during quarantine in March-June of 2020, 68.8\% of the respondents were satisfied with the service, while $28.1 \%$ indicated "hard to say". The teachers' responses are summarized in Fig. 6.

\section{Are you satisfied with the Zoom service as a means for teaching a foreign language? 32\&nbsp;ответа}

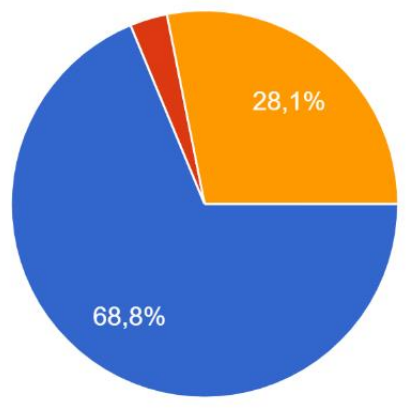

Satisfied

Unsatisfied

Hard to say

Figure 6. The level of foreign language teachers' satisfaction with the Zoom service

The results of the survey, as well as our own experience of using the Zoom service set the stage for making the following conclusion: conducting foreign language classes via Zoom video conferencing has its own specifics, but at the same time it is effective and allows achieving learning aims and objectives in case of proper use of all available training tools and functions of this service. The new mode of distance teaching, in which foreign language teachers were urgently immersed during quarantine in the spring of 2020, showed that most of them experienced technical, methodological and psychological difficulties due to the peculiarities of teaching via video conferencing. All this requires a thorough scientific study of the issue of teaching foreign languages via video conference in order to identify all the aspects of the described difficulties and to formulate ways to prevent and / or overcome them. Further in this article we will focus on the guidelines for organizing and conducting classes in a foreign language via Zoom video conferencing.

The guidelines are aimed at helping teachers to make decisions and implement them successfully during online foreign language teaching via Zoom video conferencing. Our recommendations are based on the analysis of educational and methodological literature, sources of applied character, as well as the interpretation of the survey results and our own experience of using Zoom for teaching legal English at Taras Shevchenko National University of Kyiv.

One of the most important aspects of distance education is the cyber security of its participants. Since there have been complaints about the Zoom service during the quarantine because of its low level of security [15], we strongly recommend not to neglect preventive measures to ensure it. Our recommendations include the following:

$\checkmark$ minimize the use of personal meeting ID (PMI) for training sessions;

$\checkmark$ turn on the "Waiting Room" function;

$\checkmark$ admit only registered users; 
enable the Block Conference feature after all participants have joined

Despite the fact that video conferencing involves interpersonal communication in real time, the participants are separated geographically, which, in its turn, can affect their behaviour during online meetings. In this context, we would like to indicate the main technical capabilities to maintain discipline during Zoom meetings:

$\checkmark$ the host of the videoconference (a teacher) can turn off the audio and video of all participants of the meeting, as well as an individual student;

$\checkmark$ the teacher can remove any participant from the video conference or transfer him/her to the waiting room;

$\checkmark$ in case of a student's misconduct, the teacher also has the opportunity to make remarks to him/her in the correct form by writing a personal message in the chat.

The success of distance teaching directly depends on psychological comfort, which plays an important role in the cognitive aspect, supporting the acquisition and comprehension of new knowledge [19, p. 150]. The psychological comfort of the learning environment is mostly ensured by the friendliness of its participants. We highly recommend making comments correctly and individually via a personal chat message. We do not recommend turning off video cameras, but students should be informed and helped (if necessary) on how to change the background to ensure their privacy. The teacher should calmly respond to any technical problems with connection, whether they happen to him/her as a host or students as participants. Whenever possible, the teacher should provide the necessary technical support. If the teacher is unable to solve a technical problem, he/she can appoint another student as a host; it gives the teacher time to find the way out.

It is also important to maintain a high level of students' motivation to learn. To do this, we recommend using short videos and presentations for better perception of information by students as well as using a virtual board with the possibility of sharing in order to immerse all students in the learning process. A creative idea would be to change the background corresponding to the topic of the lesson.

Achieving the set learning aims and objectives during online classes is ensured with using all the tools of the Zoom service. Thus, we recommend using a virtual whiteboard to present new material. With this tool, all participants can type, edit and delete text, draw, select necessary snippets of information, or undo a previous action. The online board has 10 pages in case the amount of material that the teacher demonstrates does not fit one page.

For the development of language skills and speech abilities, the screen sharing function will be effective; it allows the teacher to demonstrate files in doc and pdf format, PowerPoint presentations, audio and video files, etc.

To develop productive speaking skills, we recommend such activities as discussion, debate, individual or group presentations. Group and pair work can be carried out by dividing the video conference room into separate ones. To develop writing skills, the teacher can use a Google drive with open file access. Students can also complete a written assignment on a personal computer and submit it via chat as a personal message.

A significant advantage of online teaching via Zoom video conferencing over face-toface teaching is the availability of recording a meeting. It creates a unique opportunity to analyze each lesson and allows teachers to identify both methodologically effective teaching methods and techniques and the aspects that require refinement or elimination. Video recording of the meeting will also be useful for a careful analysis of students' oral responses, as well as peer review of students' work (when a video recording of one student's response is sent for analysis and evaluation to another).

In this research, we also consider it important to pay some attention to such aspect of online teaching via video conferencing as the assessment of students' achievements. In this context, it is worth noting the problem of students cheating and non-compliance with the rules 
of academic integrity. We recommend giving individual projects or the tasks that involve the expression of students' own opinion as often as possible. Such assignments as writing a letter, preparing a presentation or speech, translating a text seem to be the most appropriate and effective. We strongly advise against overloading students with an excessive number of exercises, but setting clear and sufficient deadlines for their implementation.

\section{CONCLUSIONS AND PROSPECTS FOR FURTHER RESEARCH}

The interpretation of the results of a survey conducted among foreign language teachers of Ukrainian higher education institutions, as well as our own practical experience of using the Zoom service for teaching a foreign language reveal the advantages and disadvantages of the Zoom service in the context of its use for teaching foreign languages, identify the factors that provide psychological comfort, as well as conditions and tools for the development of students' language skills and speech abilities. The research allows us to come to the conclusion that during the quarantine introduced in March-June of 2020, video conferencing became the tool that ensured the achievement of educational goals and objectives. We have proved that the Zoom service has all the technical capabilities to organize and conduct trainings in foreign languages in higher educational institutions. Moreover, it allows creating a psychologically comfortable atmosphere for such trainings, and its various toolkits provide for the development of students' necessary language skills and speech abilities. Almost 70\% of the respondents positively assess the technical capabilities of the Zoom service in the context of its use at foreign language classes. Teachers actively used the Zoom toolkit to develop students' lexical and grammatical skills, as well as their speech abilities in reading, listening, writing and speaking. This allows us to conclude that learning foreign communication via Zoom video conferencing, despite its difference from face-to-face teaching/learning, is able to ensure the formation and development of foreign language competence, provided that recommendations for the prevention of potential difficulties in planning, preparing and conducting practical foreign language classes are met. We substantiated the need and suggested the ways that can ensure participants' cybersecurity during the educational process, create a psychologically comfortable learning atmosphere, minimize technical difficulties associated with using the Zoom service, and effectively employ all the tools of the service for interesting interactive foreign language classes.

The conducted research is one of the first attempts in Ukraine to study the practical experience of using the Zoom service by teachers of Ukrainian higher educational institutions for the development of their students' foreign language competence. The issues raised in this study concern not only the linguodidactic features of foreign language teaching/learning via video conferencing, but also the psychological and technical aspects of synchronous distance teaching/learning. The presented data can be of particular scientific interest for researchers studying psychological aspects of distance education, as well as for those whose research concerns the theory and practice of ICT in education; they can also become a sound basis for further research in the field of methodology of distance teaching of foreign languages via video conferencing.

The presented results do not cover all aspects of the issues raised. In terms of the prospects for further research we suggest that the comprehensive methodology of foreign language teaching via video conferencing should be developed. 


\section{REFERENCES (TRANSLATED AND TRANSLITERATED)}

[1] GlobalLogic. Demand for video conferencing services has increased more than 7 times. [Online]. Available: https://www.globallogic.com/ua/about/news/video-conferencing-services/. Assessed on: Aug. 7, 2020. (in Ukrainian)

[2] Letter of the Ministry of Education and Science of Ukraine on the organization of current, semester control and certification of students with the use of remote technologies. [Online]. Available: file:///C:/Users/\%D0\%9E\%D0\%BB\%D0\%B5\%D0\%B3/Downloads/5ebd47497d41e067624981.pdf. Assessed on: Aug. 7, 2020. (in Ukrainian)

[3] K. Katula, "Teaching a foreign language in a desktop videoconferencing environment", Teaching English with Technology, vol. 16(3), 2016, pp. 37-51. (in English)

[4] P. McAndrew, S. P. Foubister, and T. Mayes, "Videoconferencing in a language learning application", Interacting with Computers, vol. 8, no. 2, 1996, pp. 207-217. (in English)

[5] B. Loranc-Paszylk, "Videoconferencing as a Tool for Developing Speaking Skills" in Issues in Teaching, Learning and Testing Speaking in a Second Language, M. Pawlak and E. Waniek-Klimczak, Eds. Springer-Verlag, Berlin, Heidelberg, 2015, pp. 189-203. (in English)

[6] L.-T. Yu, "Native English speaking teachers' perspectives on using videoconferencing in learning English by Taiwanese elementary school students", The JALT Call Journal, vol. 14, no. 1, 2018, pp. 61-76. (in English)

[7] Y. Wang, "Supporting synchronous distance language learning with desktop videoconferencing", Language Learning \& Technology, vol. 8, no. 3, 2004, pp. 90-121. (in English)

[8] N.V. Mayer, "Methods of independent mastering of French-language business written communication by prospective documentologists with the use of remote technologies", phd thesis, Kyiv, 2011. (in Ukrainian)

[9] N.S. Shcherba, "Using web applications in teaching foreign languages to upper secondary school students with cerebral palsy", Information Technologies and Learning Tools, vol. 7, no. 2, 2019, pp. 71-85. [Online]. Available: https://journal.iitta.gov.ua/index.php/itlt/article/view/2557. Accessed on: August 7, 2020.

[10] V.P. Svyrydiuk, "Methods of teaching German written speech to part-time students of higher language educational institutions based on the use of a distance course", thesis abstract, Kyiv, 2007. (in Ukrainian)

[11] A. Yu. Yurzhenko, "An e-course based on the LMS MOODLE to teach "Maritime English for Professional Purpose", Information Technologies and Learning Tools, vol. 71, no. 3, 2019, pp. 92-101. [Online]. Available: https://journal.iitta.gov.ua/index.php/itlt/article/view/2512. Accessed on: August 7, 2020.

[12] I.S. Zaiarna, E-teaching English Argumentative Writing to Prospective Legal Professionals: Theory and Praactice. Lviv-Torun: Liha-Pres, 2020. 264 p. [Online]. Available: http://catalog.lihapres.eu/index.php/liha-pres/catalog/view/121/1400/3109-1. Accessed on: August 7, 2020. (in Ukrainian)

[13] I.S. Zaiarna, "The Model for E-Teaching English Reasoning Writing to Law Students Based on LMS MOODLE”, Information Technologies and Learning Tools, vol. 76, no. 2, 2020, pp. 152-162. [Online]. Available: https://journal.iitta.gov.ua/index.php/itlt/article/view/3332. Accessed on: August 7, 2020. (in English)

[14] O.V. Zhovnych, "Methods of teaching professionally oriented English written communication of future journalists by means of blog technologies", phd thesis, Ternopil, 2018. (in Ukrainian)

[15] Organization of distance learning at school. Guidelines. [Online]. Available: https://mon.gov.ua/storage/app/media/zagalna\%20serednya/metodichni\%20recomendazii/2020/metodich ni\%20recomendazii-dustanciyna\%20osvita-2020.pdf. Assessed on: Aug. 7, 2020. (in Ukrainian)

[16] Ye. Arkhipova, "The use of videoconferencing during interrogation as a means of ensuring the rights of persons participating in investigative and judicial actions”, Criminal law, № 5, pp. 104-109, 2011. (in Russian)

[17] ZOOM. [Online]. Available: https://zoom.us/. Assessed on: Aug. 7, 2020. (in English)

[18] Survey on the implementation of practical experience of higher educational establishments regarding the use of Zoom videoconferencing in Ukraine in 2020. [Online]. Available: https://forms.gle/Rji87kSkqLda73NL8. Assessed on: Aug. 7, 2020. (in Ukrainian)

[19] M.L. Smulson et al., Distance Education: Psychological Grounds. Monograph, Kirovohrad, Imeks-LTD, 2012. (in Ukrainian) 


\title{
ZООМ ЯК ІНСТРУМЕНТ ВЕБ-ОРІЄНТОВАНОГО НАВЧАННЯ ІНОЗЕМНОЇ МОВИ СТУДЕНТІВ ЗАКЛАДІВ ВИЩОЇ ОСВІТИ УКРАЇНИ
}

\author{
Заярна Інна Сергіївна \\ кандидат педагогічних наук, викладачка кафедри іноземних мов Інституту права \\ Київський національний університет імені Тараса Шевченка, м. Київ, Україна \\ ORCID ID 0000-0002-9464-096X \\ izaiarna@gmail.com
}

\begin{abstract}
Анотація. В умовах карантину, спричиненого пандемією коронавірусної інфекції COVID19 у всіх закладах вищої освіти України в березні-травні було запроваджене екстрене дистанційне навчання. Це спонукало викладачів іноземних мов оперативно шукати технології для реалізації навчального процесу, спрямованого на формування вмінь іншомовного мовлення. Одним із найбільш популярних способів вирішення даної проблеми стали сервіси для відеоконференцій, зокрема Zoom. Разом з тим аналіз теоретичних праць 3 методики дистанційного навчання іноземних мов засвідчив, що проблема викладання іншомовного спілкування засобами відеоконфереції не була предметом спеціального дослідження і вимагає грунтовного наукового вивчення в контексті її використання в українських реаліях

У цій статті розглядаються особливості викладання іноземної мови у форматі відеоконференції на платформі Zoom в умовах ЗВО. У роботі представлені результати опитування, участь у якому брали викладачі іноземних мов українських закладів вищої освіти, які під час карантину в березні-червні 2020 року на своїх заняттях використовували сервіс Zoom. За результатами проведеного аналізу та інтерпретації відповідей респондентів опитування виявлено переваги і недоліки сервісу Zoom у контексті його використання під час навчання іншомовного спілкування, визначені чинники, що забезпечують психологічну комфортність, а також умови та інструменти для формування мовних навичок $\mathrm{i}$ мовленнєвих умінь. Особлива увага в дослідженні приділяється методичним рекомендаціям, спрямованим допомогти викладачам у виробленні рішень та їх практичному втіленню під час онлайн навчання іноземної мови у форматі відеоконференції на платформі Zoom. У статті розглянуті такі аспекти, як-от: забезпечення кібербезпеки під час онлайн заняття, дотримання дисципліни в ході навчання, опосередкованого технічним засобом, створення психологічно комфортної атмосфери, вивчено технічний інструментарій сервісу Zoom для навчання іншомовного спілкування.
\end{abstract}

Ключові слова: відеоконференція; викладання іноземних мов; дистанційне навчання; методичні рекомендації; COVID-19; Zoom.

\section{ZООМ КАК ИНСТРУМЕНТ ВЕБ-ОРИЕНТИРОВАННОГО ОБУЧЕНИЯ ИНОСТРАННОМУ ЯЗЫКУ СТУДЕНТОВ ВЫСШИХ УЧЕБНЫХ ЗАВЕДЕНИЙ УКРАИНЫ}

\author{
Заярная Инна Сергеевна \\ кандидат педагогических наук, преподаватель кафедры иностранных языков Института права \\ Киевский национальный университет имени Тараса Шевченко, г. Киев, Украина \\ ORCID ID 0000-0002-9464-096X \\ izaiarna@gmail.com
}

Аннотация. В условиях карантина, вызванного пандемией коронавирусной инфекции COVID-19, во всех учреждениях высшего образования Украины в марте-мае было введено экстренное дистанционное обучение. Это побудило преподавателей иностранных языков оперативно искать технологии для реализации учебного процесса, направленного на формирование умений иноязычной речи. Одним из самых популярных способов решения данной проблемы стали сервисы для видеоконференций, в частности Zoom. Вместе с тем, анализ теоретических работ по методике дистанционного обучения иностранным языкам показал, что проблема преподавания иноязычного общения средствами видеоконфереции 
не была предметом специального исследования и требует основательного научного изучения.

В этой статье автор рассматривает особенности преподавания иностранного языка в формате видеоконференции на платформе Zoom в условиях ЗВО. В работе представлены результаты опроса, участие в котором принимали преподаватели иностранных языков украинских высших учебных заведений, которые во время карантина в марте-июне 2020 году на своих занятиях использовали сервис Zoom. По результатам проведенного анализа и интерпретации ответов респондентов опроса выявлены преимущества и недостатки сервиса Zoom в контексте его использования при обучении иноязычному общению, определенные факторы, обеспечивающие психологическую комфортность, а также условия и инструменты для формирования речевых навыков и речевых умений. Особое внимание в исследовании уделяется методическим рекомендациям, направленным на помощь преподавателям в выработке решений и их практическое воплощение в ходе онлайн обучения иностранному языку в формате видеоконференции на платформе Zoom. Автором рассмотрены такие аспекты, как обеспечение кибербезопасности во время онлайн занятия, соблюдение дисциплины в условиях обучения, опосредованного техническим средством, создание психологически комфортной атмосферы, изучено технический инструментарий сервиса Zoom для обучения иноязычного общения.

Ключевые слова: видеоконференция; преподавание иностранных языков; дистанционное обучение; методические рекомендации; COVID-19; Zoom.

This work is licensed under Creative Commons Attribution-NonCommercial-ShareAlike 4.0 International License. 